\title{
アルミン酸ナトリウム溶液からの水酸化アルミニウムの 析出速度に対する種子および不純物の影響十
}

(昭 和 37 年 3 月 20 日 受理)

$$
\text { 下 里 純 一 郎* }
$$

\begin{abstract}
アルミン酸ナトリウム溶液からの水酸化アルミニウムの析出速度に関する反応条件の影響を前報に引続き論じた。反応 条件として種子の特性, 種子量, 不純物を選び, これらの要因を変化させた実験に従来の文献上の実験例を参考として析 出速度に対する影響を調べた結果, 析出速度はそれぞれの要因によって次のよ5に影響される。（1）種子としては不安 定で活性に富んだ水酸化アルミニウムが, 析出をより促進する。活性種子の製造法としては高アルカリ濃度や高過飽和度 からの析出, 炭酸ガス吹込による析出, または酸性アルミニウム塩類の添加による析出がある。（2）同一の結晶形態並 びに表面状態では粒度の細かい表面積の大きな水酸化アルミニウムが促進作用が強い。（3）同一の表面状態で同一の粒 度を有する種子を与える時は，種子量が多いほど析出速度を早めるが，その量には限银があり活性種子ほど，その限界の 種子量は低い。（4）析出促進剤としてのフッ化アルミニウム，塩化アルミニウムの作用を考察し，かつその析出物の粒 度が異常に細かいことを示した。（5）液中の不純物の多、のものは析出を阻止するが，炭酸ナトリウムのみは析出を促 進する作用がある。
\end{abstract}

\section{1 緒 言}

前報1) に引続きアルミン酸ナトリウム溶液からの水酸化アルミ ニウムの析出速度に関して，析出条件の影響を論ずる。本報に特 いては本来析出速度の小さなこの反応を促進するために使用され る種子について，その性状並びに添加量の影響を調べ, 活性種子 製造の際に使用される析出促進剂の効果を述べ, 更に工業用アル ミン酸ナトリウム溶液においては避けることのできない不純物の 影響について論じた。

\section{2 種子の種類}

アルミン酸ナトリウム溶液からの水酸化アルミニウムの析出速 度は遅いので, 実用上析出速度を促進させるためにはすべて種子 添加に底存しなければならない。種子として主に実用に供せられ る物には, 特別に低温析出によるか, 析出促進剤を用いた析出に よって製造された微粒水酸化アルミニウムを使用する方法と, 析 出した水酸化物中の細粒部分を使用する方法の二つがある。

\section{$2 \cdot 1$ 誘導期間}

析出反応に対する種子の影響を論ずる前に種子なしの場合の過 飽和アルミン酸ナトリウム溶液の安定性について述べる。アルミ

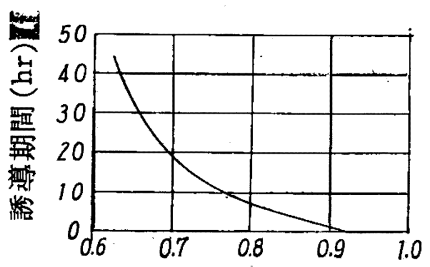

液モル比 $\left(\mathrm{Al}_{2} \mathrm{O}_{3} \mathrm{~mol} / \mathrm{Na}_{2} \mathrm{O} \mathrm{mol}\right)$

図 1 アルミン酸ナトリウム溶液 の誘導期間 (Vrabski Kよる)
ン酸ナトリウム溶液の安定度 はKuznetsov ${ }^{2}$ によって実験 が行われているが, 過飽和度 が大きいほど不安定になると している。安定度を調べるに は，核の発生するまでの誘導 期間を知るのが，より定量的 である。すなわち，誘導期間 の長さは核発生の速度を表わ
†本報を「アルミナ製造工程より見たアルミン酸ナトリウム 溶液からの水酸化アルミニウムの析出反応 (第 4 報)」と する。

* 昭和ネオプレン株式会社技術部：東京都港区芝宫本町 34 .

1) 下里, 古川, 高橋, 工化 65,1787 (1962).

2）S. I. Kuznetsov，牧野，フルミナ製造法 p. 52 (1956) 冶 金図書出版書（russ.）
するのといえよ5。Vrabski $\left.{ }^{3}\right)$ は $\mathrm{NaOH} 88 \sim 128 \mathrm{~g} / l, \mathrm{Al}_{2} \mathrm{O}_{3} 97$ $\sim 102 \mathrm{~g} / l$ の溶液で $30^{\circ} \mathrm{C}$ に拈ける誘導期間を測定し図 1 のよ5 な結果を得ている。原論文ではモル比 0.72 の付近で変曲点があ るとし, これょり濃度の濃い方では, 液の構造に変化があるとし ているがそれほど明白ではない。しかしながら，誘導期間はモル 比大 $\left(\mathrm{Al}_{2} \mathrm{O}_{3}\right.$ 濃度がほぼ一定であるから $\mathrm{NaOH}$ 濃度小) なる方 が不安定になることを示しており，その傾向は Kuznetsov の実 験と一致している。

佐藤

$$
U=\frac{C_{\mathrm{a}}-C_{\mathrm{as}}}{C_{\mathrm{as}}}
$$

と誘導期間の関係を図 2 のよ5に示している。ただし $U$; 過飽 和度， $C_{\mathrm{a}}$; 液中アルミナ濃度， $C_{\mathrm{as}}$; アルミナ平衡濃度とする。

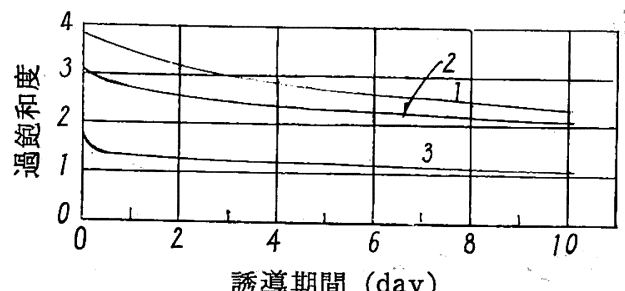

図2 アルミン酸ナトリウム溶液の誘導期間 （佐藤に上る）

$$
\begin{aligned}
\mathrm{NaOH}(\mathrm{g} / l) \\
1: 80 \quad 2: 140 \quad 3: 240
\end{aligned}
$$

同じ過飽和度では，アルカリ濃度が大なるにしたがって，誘導期 間が短く不安定になるのは興味ある事実である。これは前報に述 ベたとおり，アルカリ濃度が濃くなると，液中に打けるアルミン 酸イオンの相互作用が密接になってくることを物語っている。し たがって、このことが核発生を行ない易くし, 誘導期間を短くし ている。

以上のよ5にアルミン酸ナトリウム溶液は過飽和度の大きくな い範囲では非常に長い誘導期間があって後, 析出が開始される。

\section{$2 \cdot 2$ 種子の種類並びにこれに関する実験例}

工業的に使用される種子には特別に製造された水酸化物を使用

3) T. Vrabski et al, Can. J. Chem. 36, 1410 (1958).

4) 佐藤, 工化 54, 756 (1951). 
することがある。これは主として析出を促進させるために，微粒 で不安定かつ表面積の多い水酸化アルミニウムを製造することとが 目的とされるので,いわゆる活性種子と名付けることができよう。 活性種子の製造法は主として次の三通りに大別される。

（1）低温冷却析出によるもの

（2）酸性のアルミニウム塩類添加によるもの

（3）炭酸ガス吹込によるもの

低温冷却による種子の製造は主としてヨーロッパにおいて多く 行なわれ析出槽仕込液を熱交換または単なる冷却によって 30〜 $40^{\circ} \mathrm{C}$ の低温として析出を行なわせ，微細な水酸化アルミニウム 結晶を得るものである。

アルミニウム塩類添加にはフッ化アルミニウム, 塩化アルミニ ウム等のように酸性の強い塩類を $40 \sim 50^{\circ} \mathrm{C}$ の低温にした過飽和 アルミン酸ナトリウム溶液内に投入し，急激な析出を行なわせて 微細な種子を得るものである。この際添加剤としては塩化アルミ ニウムを用いて析出した水酸化物がもっとも活性に富む種子を得 ることができ，これに次いで硫酸アルミニウム，フッ化アルミニ ウムが種子として適している。添加剤をアルミナ換算で溶液中の アルミナ分の $1 \sim 3 \%$ 程度添加して水酸化アルミニウムを析出さ せ種子を製造した篠原 ${ }^{5}$ ) の実験によるとフッ化アルミニウム添加 析出による種子と塩化アルミニウム添加析出による種子を使った

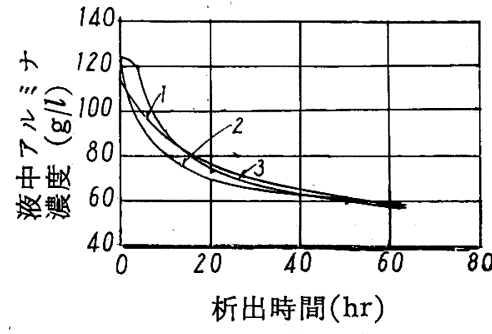

因 3 析出曲線一種子の影響 （箫原による）

1:フッ化アルミニウム添加析出による種子 $5 \%$ $2:$ 塩化アルミニウム添加析出による種子 $5 \%$

$3:$ 通常の析出による程子 $50 \%$ 時の析出曲線は図 3 のよ らである。ただし $\mathrm{NaOH}$ $155 \mathrm{~g} / l$, モル比 0.64 の 工業用アルミン酸ナトリ ウム溶液を使用し, 種子 量はアルミナ換算 $5 \%$ で 析出温度は $45^{\circ} \mathrm{C}$ である。 比較のため, 前報の実験 に怙ける $\mathrm{NaOH} 153 \mathrm{~g} / l$, モル比 0.66 の液組成で 粗粒水酸化物を使用した 種子量 $50 \%$ 。条件の析出曲線の中, $40^{\circ} \mathrm{C}$ と $50^{\circ} \mathrm{C}$ の平均曲線を 載せたが活性種子は通常の粗粒種子の $1 / 10$ の添加量でもほぼ同 等の析出速度を得られ，乙かも析出初期に扣ける核発生のために 起る析出の遅れがないことからも，これらの活性種子が十分の数 の核を最初から保有していることが判明する。

炭酸ガス吹込みによるものも添加剤使用と原理的には同じであ って, 液の一部のアルカリ度を下け゚，急速に微細な結晶を析出さ せる。この方法によれば結晶としてはパイヤライトを得る。炭酸

表 1 析出実験に用いられた種々の種子(佐藤による)

\section{析出条件}

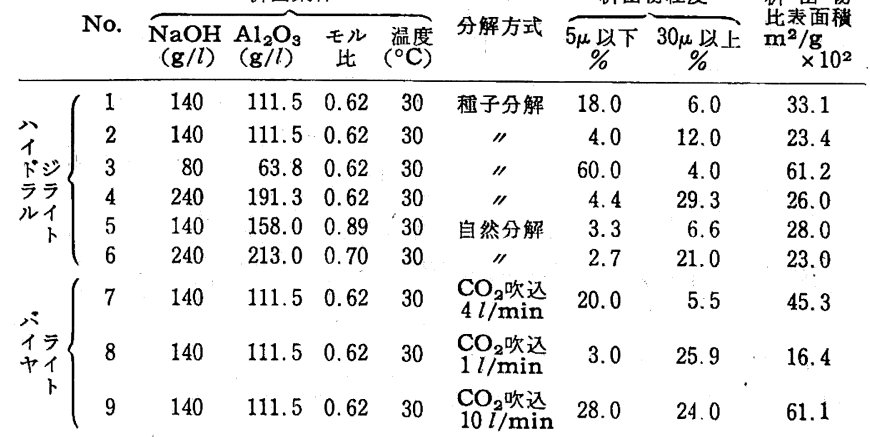

5）篠原，昭和電工横浜工場報 157 (1955).

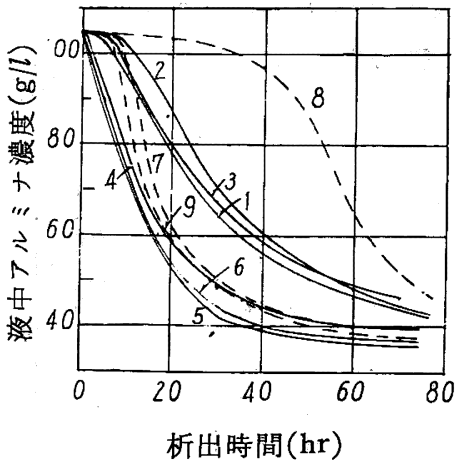

図 4 析出曲線-種子の影響 ( N ) (佐藤による) -ーー パイライト秏子
— ハイドラルジライト種子
ガスの吹込み速度が早く， 溶液が低温であるほと活性 のある結晶が得られる。佐 藤6) の実験において行なわ れた種々の特性値を持った 種子（表 1 参照）を用いて $\mathrm{NaOH} 140 \mathrm{~g} / l$, モル比 0.59 , $30^{\circ} \mathrm{C}$ の析出条件における る。ハイイライトの種子量 はハイドラルジライトの種 子量の $1 / 50$ であるにもか かわらず,一つを除いてほ 結果は図 4 のと打りであ

ぼ同等の析出速度を得ていることから考えれば, 種子としてバイ ヤライトは元来が不安定な結晶であるから，活性に富んでいると いらことがいえよう。この実験では, 大体において同一の条件で 生成した種子を比較すると, 粒度の細かい方が析出速度を促進し ている。これは種子としての反応表面積が大なるためと考えられ る。しかるにアルカリ濃度が大なる条件が得られた種子は, 粒度 が大きいにもかかわらず析出速度を早くする。したがって，かか る場合には結晶表面の安定度が析出速度を促進する度合を决める ものと考えられ，アルカリ濃度が大なる液は，本来不安定である から，不安定な活性核を生成しているものと考えられる。同様に 自然分解で得た種子はこの実験では, たまたま過飽和度の高く, アルカリ濃度の高い条件から析出して得られた結晶であるから， 表面状熊はすこぶる活性に富んでいたものと推察される。

その他に更に各種の種子を使った実験例を示すと, 北野7は種 子の生成条件として
A. $\mathrm{NaOH} 100 \mathrm{~g} / \mathrm{l}$, モル比 $0.66,50^{\circ} \mathrm{C}$, 種子量 $10 \%$
B. $\mathrm{NaOH} 75 \mathrm{~g} / \mathrm{l}$
C. $\mathrm{NaOH} 50 \mathrm{~g} / \mathrm{l}$

"

で析出した 3 種の種子を用いて， $\mathrm{NaOH} 130 \mathrm{~g} / l$, モル比 0.66 , 温度 $50^{\circ} \mathrm{C}$, 種子量 $5 \%$ で実験した結果, やはりアルカリ濃度の 高いものから得られた種子の方が析出速度を早めることを認めて いる。更に Herrmann ${ }^{8)}$ は次の種子
1. 平均粒径 $0.4 \mu$ バイヤライト
2. $11 \quad 1 \mu$ ハイドラルジライト
3. " $20 \mu$ "

を使って, $\mathrm{NaOH} 141 \mathrm{~g} / l$, モル比 0.56 , 初温 $55^{\circ} \mathrm{C}, 96$ 時間後

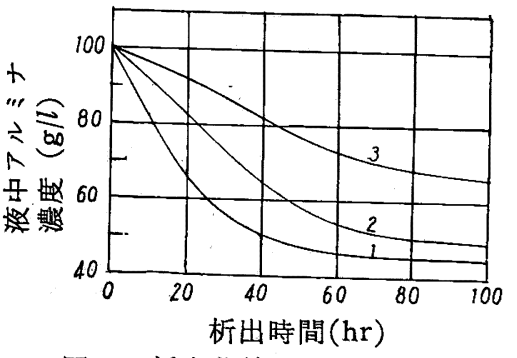

図 5 析出曲線-種子量の影響 (Herrmann Kよる) の終温 $40^{\circ} \mathrm{C}$ の析出条 件において実験してい る。この場合には種子 量が $1 ; 0.15$ vol\%, $2 ; 1.54$ vol\%, $3 ; 17$ vol\%（vol\% は液中 アルミナ濃度に対する アルミナ換算種子量\% のほぼ 1.6 倍に相当す

6) 佐藤, 工化 56,399 (1953) ; 56, 743 (1953).

7) 北野, 昭和電工横浜工場報 119 (1951).

8) E. Herrmann, J. Stipetić, Z. anorg. Chem. 262, 258 (1950). 
る）で粒度の最も細かい 1 の種子は最も種子量が少ないにもかか わらず，析出速度が最大である(図 5 )。

種子の他の種類としては，アルミナ烧成用キルンで回収したが ストがありこれは灼減 $10 \%$ 程度のもので, 有機物は然烧して 除去されるから，活性 に富んでいるともいわ れるが，実験上からは 乾燥または焼成を経た 水酸化物は種子として 活性が落ちる。一例と して Herrmann ${ }^{8)}$ の実 験例を図 6 に揭げる。 種子として使用したも のは,

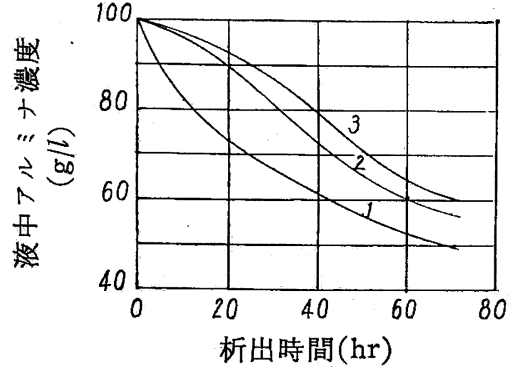

因 6 析出曲線一種子の影響 (Herrmann Kよる)

1. 平均粒径 $1 \mu$ の水酸化物種子

2. 1 を塩化カルシウムで乾燥

3. 1 を $100^{\circ} \mathrm{C} て ゙ 2$ 時間乾燥

の 3 種で, 析出条件は $\mathrm{NaOH} 141 \mathrm{~g} / l$, モル比 0.56 , 初温 $60^{\circ} \mathrm{C}$, 終温 $55^{\circ} \mathrm{C}$, 種子量は $1.1 \%$ である。図からも判明するように乾 燥水酸化アルミニウム種子を使った方が, 析出速度は遅い。乾燥 によって, 種子表面の活性核が安定性を増したためと考えられる。

また，焼成物を種子として使用した実験は佐藤”が行なってい る。焼成温度が高くなるほど, 析出速度は遅くなり， $1050^{\circ} \mathrm{C}$, $1300^{\circ} \mathrm{C}$ に焼成すると誘導期間を生ずるよ5になる。しかし自然 分解を行な5際よりす短い誘導期間で析出を開始するから，この よ5に 中においては若干の核が存在しているものとい去らっ。

\section{$2 \cdot 3$ 種子の影響に対する中間実験}

かくして種子の種類によって, 析出速度ははなはだしい影響を 受けることが判明したが, 工業的な操業条件で使用する種子の範 囲内においては，もっぱら種子の粒度によって析出速度の左右さ れることが多い。

害験の要因をアルカリ濃度, モル比, 析出初温, 種子量によっ て分類し，これらの条件を固定して種子の粒度と析出曲線の関係 を中間実験に执いて調べた。析出条件として初温 $59^{\circ} \mathrm{C}, \mathrm{NaOH}$ $158 \mathrm{~g} / l$, モル比 0.54 , 種子量 $65 \mathrm{~g} / l$ を選んだ際の析出時間 110 時間目に拈ける種子中 $10 \mu$ 以下の成分と液中アルミナ濃度との

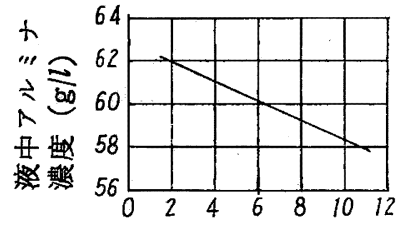

種子粒度 $10 \mu$ 以下 $(\%)$

図 7 種子粒度と液中アルミナ濃度

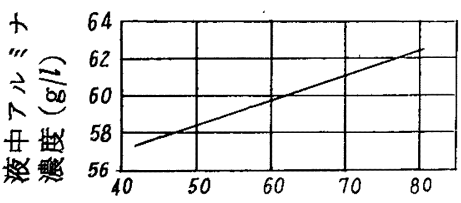

種子粒度 $40 \mu$ 以上 $(\%)$

図 8 種子粒度と液中アルミナ濃度

9）佐藤，工化 58，325 (1955).

表 2 種々の種子の析出率に刘する影響(林による)

\begin{tabular}{|c|c|c|c|c|c|c|c|}
\hline & \multirow{2}{*}{$\begin{array}{c}\text { 租子聂 } \\
(\%)\end{array}$} & \multicolumn{2}{|c|}{ 㮀子粒度 } & \multirow{2}{*}{$\begin{array}{l}\text { 初 温 } \\
\left({ }^{\circ} \mathrm{C}\right)\end{array}$} & \multirow{2}{*}{$\begin{array}{l}\text { 終 温 } \\
\left({ }^{\circ} \mathrm{C}\right)\end{array}$} & \multirow{2}{*}{$\begin{array}{l}\text { 析 出 } \\
\text { 捗 } \\
\text { (hr) }\end{array}$} & \multirow{2}{*}{$\begin{array}{c}\text { 析山辌 } \\
(\%)\end{array}$} \\
\hline & & $\begin{array}{l}10 \mu \mathrm{W} \\
F(\%)\end{array}$ & $\begin{array}{l}40 \mu \text { 以 } \\
L(\%)\end{array}$ & & & & \\
\hline$A$ 程子 & $\begin{array}{l}7 \\
7 \\
7\end{array}$ & $\begin{array}{c}50.2 \\
" 1 \\
" 1\end{array}$ & $\begin{array}{l}2.9 \\
11 \\
11\end{array}$ & $\begin{array}{l}56 \sim 62 \\
70 \sim 74 \\
77 \sim 80\end{array}$ & $\begin{array}{l}38 \sim 44 \\
47 \sim 48 \\
45 \sim 50\end{array}$ & $\begin{array}{l}96 \\
95 \\
99\end{array}$ & $\begin{array}{l}53.2 \\
51.0 \\
50.0\end{array}$ \\
\hline B程子 & $\begin{array}{l}26 \\
26 \\
26\end{array}$ & $\begin{array}{c}13.9 \\
" 1 "\end{array}$ & $\begin{array}{c}21.6 \\
" 1 "\end{array}$ & $\begin{array}{c}57 \sim 63 \\
65 \\
76 \sim 79\end{array}$ & $\begin{array}{c}41 \sim 48 \\
45 \\
48 \sim 52\end{array}$ & $\begin{array}{r}95 \\
94 \\
95.6\end{array}$ & $\begin{array}{l}53.3 \\
53.3 \\
51.2\end{array}$ \\
\hline $\mathrm{C}$ 秛子 & $\begin{array}{l}26 \\
26 \\
26\end{array}$ & $\begin{array}{c}15.1 \\
\text { "I }\end{array}$ & $\begin{array}{c}19.4 \\
" 1\end{array}$ & $\begin{array}{l}57 \sim 62 \\
68 \sim 73 \\
78 \sim 79\end{array}$ & $\begin{array}{l}40 \sim 49 \\
43 \sim 48 \\
47 \sim 56\end{array}$ & $\begin{array}{r}93 \\
100 \\
95.5\end{array}$ & $\begin{array}{l}52.3 \\
50.3 \\
50.0\end{array}$ \\
\hline
\end{tabular}

$3 \sim 6$ の結果からも判断される。

林 ${ }^{10)}$ の行なった中間実験において種々の種類の種子を析出した 結果を表 2 に示す。表中 $A$ 種子は低温冷却による種子， B， C 種 子は粗粒種子である。粒度の細かい種子は種子量が少なくとも粒 度の粗い種子とほぼ同程度の析出率を得ている。

析出する水酸化物の一部を戻して種子に使用する工業的な条件 に和いては, 結晶の形態の著しく異なった水酸化アルミニウムは 生じ得ないから, 種子の活性度はむっぱら種子の粒度によって代 表し得る。

\section{3 種子量}

水酸化アルミニウムの析出速度は種子の活性度が富むほど大に なるが，同じ種類の種子を使用する場合にはその種子の表面積す なわら種子量が析出速度を左右することになる。したがって, 種 子量を多くすれば析出速度は早くなるが，一定の析出条件では限 界があり，ある種子量以上を加えても析出速度をほとんど增加さ せぬようになる。

\section{$3 \cdot 1$ 種子量の影響に関する析出実験}

種子量と析出速度の関係を求めた実験としては岡田 ${ }^{11)}$ の研究が

た。また，同じ条件に括け る種子中 $40 \mu$ 以上の成分 と液中アルミナ濃度との関 係は因 8 亿示される。細粒 部分の液中アルミナ濃度に 対する影響は粗粒部分のそ れよりる大きい。

これは種子粒子の表面積 が細粒部分によって左右さ れるためである。この条件 よりも析出時間が短くなれ ば，更に液中アルミナ濃度 に差を生じて来ることは図

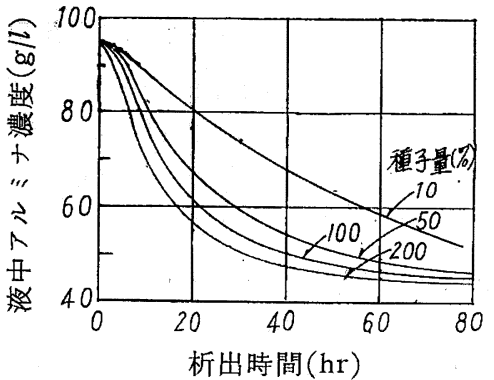

図 10 析出曲線一種子量の影響 (Kuznetsov 䏓よる)

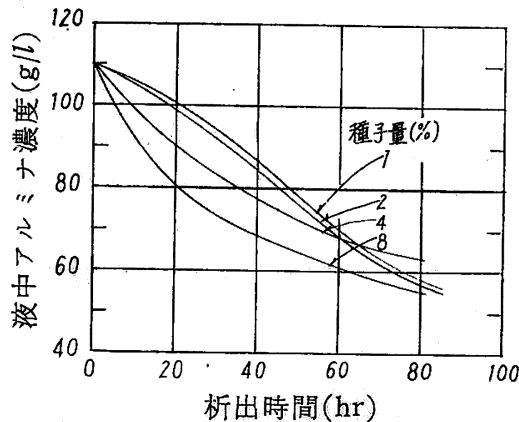

因 9 析出曲線一種子量の影響 (岡田注よる)

ある。 $\mathrm{NaOH} 149 \mathrm{~g} / l$, モル比 0.60 , 温度 35 ${ }^{\circ} \mathrm{C}$ の析出条件飞扣い て,フッ化アルミニウ ム添加析出によって得 られた活性種子を用い た結果，図 9 のごとき 曲線を得ている。

Kuznetsov ${ }^{12)}$ : は次 の粒度を有する水酸化 アルミニウム種子を用

$20 \mu$ 以下 $8 \%$ $30 \mu$ 以下 $32 \%$ $52 \mu$ 以下 $45.5 \%$ $62 \mu$ 以下 $69 \%$ $74 \mu$ 以下 $84 \%$ W $\mathrm{NaOH} 142 \mathrm{~g} / l$, 儿比 0.53 , 温度 $61^{\circ} \mathrm{C}$, 終温 $40^{\circ} \mathrm{C}$ で実験を行 ない，図10のような 結果を示している。こ

10）林, 昭和電工横浜工場報 A 15 (1957).

11）岡田，昭和電工横浜工場報 155 (1955).

12) S.I. Kuznetsov, Zhur, Priklad. Khim. 30, 352 (1956) (Russ.) 


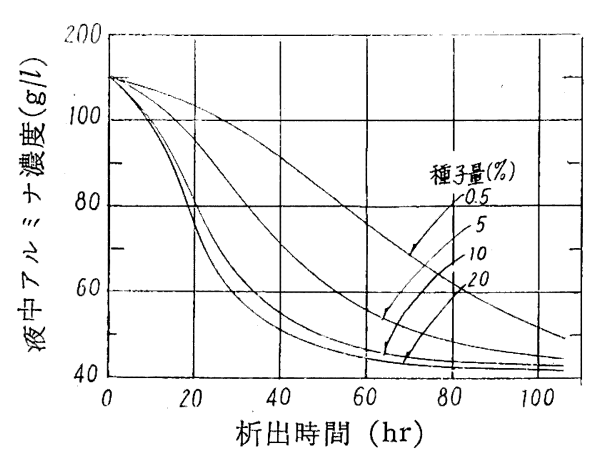

図 11 析出曲線-種子量の影響

の実験では種子量 $50 \%$ 以上は余り効果的でなかった。

佐藤 ${ }^{13)}$ は $30^{\circ} \mathrm{C}$ で低温析出させた活性種子（5 $\mu$ 以下 $17 \%$, $30 \mu$ 以上 $6 \%$ ) を用い, $\mathrm{NaOH} 140 \mathrm{~g} / l$, モル比 $0.62, \mathrm{Al}_{2} \mathrm{O}_{3}$ $110 \mathrm{~g} / l$, 温度 $30^{\circ} \mathrm{C}$ で恒温析出を行なったが, その結果は図 11 のごとくで, 種子量 $10 \%$ 以上は析出速度の增加は少ない。以上 の実験例から見られる特徴は種子を増加すれば, 析出速度は著し く早まるが，むる程度以上の種子量では增加しても反応速度に及 ぼす影響が少なくなるということである。また，活性ある種子の 方が, その限界量に達するのが比較的低い種子量の水準であると 判断される。

\section{$3 \cdot 2$ 中間実験}

前記のような中間実験に执いて得られた種子量の影響を示すと 図 12 のごとくなる。析出条件は初温 $58^{\circ} \mathrm{C}, \mathrm{NaOH} 157 \mathrm{~g} / l$, モル

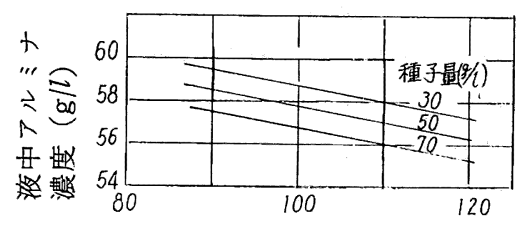

析出時間 $(\mathrm{hr})$

図 12 析出曲線-種子量の影響

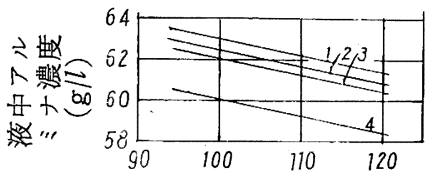

析出時間 $(\mathrm{hr})$

因13析出曲線-種子量, 種子粒度の影響 程子粒度 $40 \mu$ 以上

種子量 $(\mathrm{g} / l)$

$1: 76.5$
$2: 56.1\}$
3 $69.5 \%$

$\left.\begin{array}{l}3: 56.1 \\ 4: 76.5\end{array}\right\} 55.7 \%$
比 0.54 , 種子粒度 40 $\mu$ 以上 $65 \%$, 温度傾 斜 $\alpha=0.0043 \% 1$ であ って, 種子量 30 ない し $70 \mathrm{~g} / \mathrm{l}$ (アルミナ換 算）では析出速度を早 める效果があったが, $70 \mathrm{~g} / l$ 以上では著しい 効果はなかった。また 図 13 は初温 $59^{\circ} \mathrm{C}$, 外気温 $8.3^{\circ} \mathrm{C} ※ 2, ア ル$ カリ濃度 $158 \mathrm{~g} / l$, モル 比 0.54 におけるもの であるが，種子粒度の 粗い場合，すなわち $40 \mu$ 以上が $56 \%$ の場 合では効果が著しかっ

た。これは粒度の細かい種子の方が種子量を増加することによっ て, 反応に与かる種子の表面積を著しく増大するためと見られる。

一般には, 析出時間が長くなると, 種子量が少ないことに起因 する析出曲線の遅れは過飽和度をより大ならしめるから，末期に 至っては, 種子量が多い昜合の析出曲線に次第に近づく。したが

13）佐藤, 工化 55, 198 (1952).

※1 この実験に拈ける温度傾斜 $\alpha$ の定義については第 3 報に 述べたと持りである。析出初温 $t_{0}{ }^{\circ} \mathrm{C}, \theta$ 時間後の析出液の 温度を $t^{\circ} \mathrm{C}$ とすると $t=t_{0} \exp (-\alpha \theta)$ なる関係が近似的に 得られた（ただし不連続式析出に拈いて）。

$※ 2$ 外気温と温度経過の関係については, 第 3 報に述べたと拉 りである(ただし連続式析出に执いて)。外気温が低いほど， その下降速度は急になる。
って,析出時間が長ければ種子量の影響は減少して行く。また,林 の行なった実験では, 前記のB種子を利用して種子量を変化した 結果, 次のごとくなった。析出条件としては初海 $60^{\circ} \mathrm{C}$, 終温 $33^{\circ} \mathrm{C}$,

$\begin{array}{llccc}\text { 種子添加量 } & \% & 4 & 17 & 30 \\ \text { 析 出 率 } & \% & 45.5 & 49.5 & 53.5\end{array}$

析出時間 96 時間, $\mathrm{NaOH} 154 \mathrm{~g} / l$, モル比 0.52 である。この結 果より判断すれば，種子量は $50 \%$ 程度をで効果を生す゚るようで ある。

\section{4 析出促進剂}

アルミン酸ナトリウム溶液中に, フッ化アルミニウム, 硫酸ア ルミニウム, 塩化アルミニウム等を添加すると, これらの塩が溶 解する際に溶液中に $\mathrm{OH}^{-}$濃度の低い部分ができ, これが過飽和 溶液の過飽和度を部分的により大にし, 水酸化アルミニウムの微 粒子を発生して核を作る。したがって, これらの塩類の添加は析 出速度を早めるのに著しい寄与をするのが通例である。しかし, 溶液の過飽和度が余り高くない時には, いったん発生した水酸化 アルミニウム微粒子が逆に溶解し去ることもあり, 析出速度を何 ら促進し得ない。

篠原 ${ }^{14)}$ は $\mathrm{NaOH} 150 \mathrm{~g} / l$, モル比 0.68 , 析出温度 $45^{\circ} \mathrm{C}$ に和い て種子量は液中のアルミナ濃度の 1 当量で種々の添加物を加えて

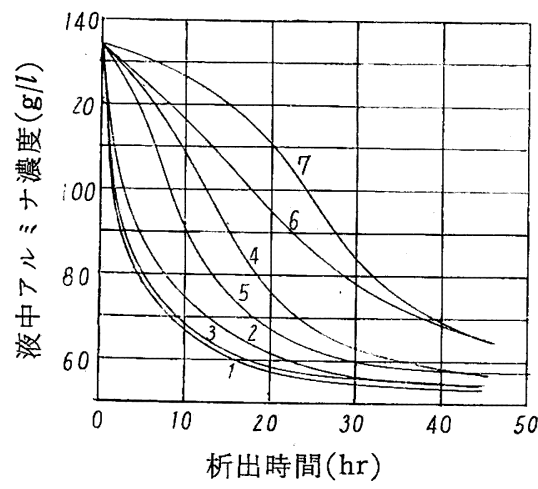

図 14 析出曲線一促進剤の影響 (策原比よる)

1: $\mathrm{AlCl}_{3} \cdot 3 \mathrm{H}_{2} \mathrm{O}$

2: $\left(\mathrm{NH}_{4}\right) \mathrm{Al}\left(\mathrm{SO}_{4}\right)_{2} \cdot 12 \mathrm{H}_{2} \mathrm{O}$

$3: \mathrm{Al}_{2}\left(\mathrm{SO}_{4}\right)_{3} \cdot 18 \mathrm{H}_{2} \mathrm{O}$

$4: \mathrm{HF}$

$5: \mathrm{AlF}_{3} \cdot 3 \mathrm{H}_{2} \mathrm{O}$

$6:$ フッ化物添加による程子

$7:$ 無程子
析出を行なっている。 その結果は図 14 のよ うになって, 最も溶解 速度の早いと考觉られ る塩化アルミニウムが 最大の促進作用を示し た。ただ注目すべきは フッ化アルミニウムと 塩化アルミニウムと塩 酸を比べた場合に，い ずれも前者の方がすぐ れた促進作用を有して いることである。この ような微量の添加の際 には酸類は余りに早く フッ化水素酸あるいは 溶解されてしまって，

液中に $\mathrm{OH}^{-}$の少ない部分を形成する時間が瞬間的であるために, 水酸化アルミニウムの微粒子を生成するに都合の悪いこと, 一方,

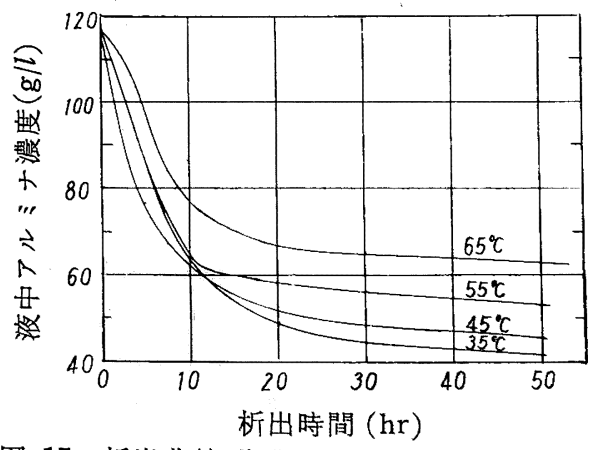

図 15 析出曲線一塩化アルミニウム添加の場合 （箫原に上る）

14）篠原，昭和電工横浜工場報 157 (1955). 
アルミニウム塩類では溶解と同時に $\mathrm{OH}^{-}$の少ない部分に同時に $A 1^{3+}$ が隣り合って溶解するから，これが水酸化アルミニウム微 粒子を形成するのに有效であるためと考兄られる。また, 彼の実 験で $\mathrm{AlCl}_{3} \cdot 3 \mathrm{H}_{2} \mathrm{O}$ を3当量\%添加し, $\mathrm{NaOH} 153 \mathrm{~g} / l$, モル比 0.60 の条件に打いて $65,55,45,35^{\circ} \mathrm{C}$ の各温度で実験を行なっ た結果は図 15 の曲線で示される。普通の種子添加の析出と比較 すると, この場合の析出初期の温度依存性は若干異なる。すなわ ち、種子添加の場合は析出初期の速度は $70^{\circ} \mathrm{C}$ ) までは温度が高 いほど析出速度が早かったが，この場合は温度が高いとか党って 析出速度が遅れ, $45^{\circ} \mathrm{C}$ 付近が最大の析出速度を示す。すなわち, $45^{\circ} \mathrm{C}$ 以上では温度が高いと溶液の過飽和度が低いために塩化物 添加によって生じた水酸化アルミニウム微粒子が溶解し去る割合 が多くなり， $45^{\circ} \mathrm{C}$ 以下では反応速度低下を受けるためと考兄ら れる。更に, 岡田 ${ }^{15}$ や篠原の実験によればフッ化アルミニウム, 塩化アルミニウムともに結晶水を含んでいるものの方が析出初期 の反応速度の早いことを示している。これは結晶水を有する塩の 方が溶解速度の早いためである。

Kuznetsov2) ${ }^{2}$ はアルミン酸ナトリウム溶液に塩化アルミニウム， フッ化アルミニウム, 硫酸アルミニウムのそれぞれの溶液を液中 のアルミナの $0.4 \sim 1$ 当量 \% 添加して, 最初コロイド状水酸化 アルミニウムの雪片の生成を観察したが，ただちに消失したと報 告している。これは生成した水酸化アルミニウム微粒子の粒径が その時の条件に括ける液濃度では，溶解度の範囲内にはいってい たためとみるべきであろう。

アルミニウム塩類を析出促進剤に使用した時に発生する水酸化 アルミニウム粒子は, 部分的に過飽和度を高めた状態から生ずる ので, 当然析出粒子は細かくなって来る。 $\mathrm{AlF}_{3} \cdot 3 \mathrm{H}_{2} \mathrm{O}$ の添加量 を变化させて $\mathrm{NaOH} 155 \sim 160 \mathrm{~g} / l$, モル比 $0.53 \sim 0.58$, 初温 50

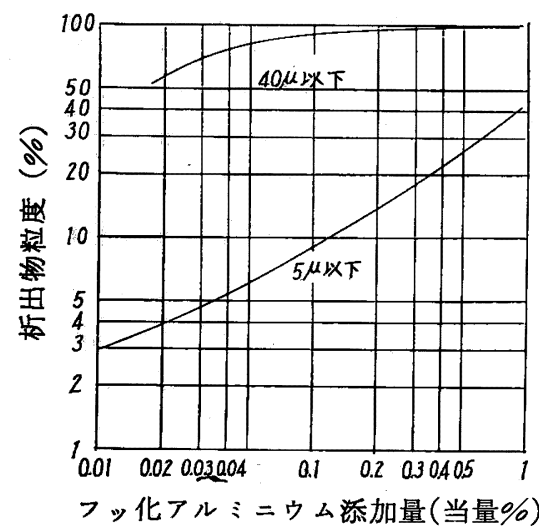
$\sim 60^{\circ} \mathrm{C}$ 前後で析出さ せた水酸化アルミニウ ムの粒度は図16のごと くなって, フッ化アル ミニウムを液中アルミ ナ汇対し 3 当量 \% 加 えれば，既に析出物の $60 \%$ 以上が $5 \mu$ 以下 の細粒になる。したが って析出促進剤は工業 的な意味としては活性

図 16 析出物粒度-フッ化アルミニウ 么添加量の影響

種子の製造に利用でき るのみで，析出促進剤 が析出速度を異常に早めるとしても，かかる細粒を口過するのは 余り得策ではない。

\section{5 不純物の影響}

アルミン酸ナトリウム溶液中の不純物は前報16)で示したと括り $\mathrm{Na}_{2} \mathrm{CO}_{3}, \mathrm{NaCl}, \mathrm{P}_{2} \mathrm{O}_{5}, \mathrm{As}_{2} \mathrm{O}_{3}, \mathrm{SO}_{3}, \mathrm{SiO}_{2}$, 有機物等が主として ナトリウム塩として存在して拈り, 純アルミン酸ナトリウム溶液 に比較すればハイドラルジライトの溶解度も高くなっているので, 析出速度になんらかの影響を及ぼすはずである。

15）岡田，昭和電工横浜工場報 156 (1955).

16) 下里, 工货 65, 1779 (1962),

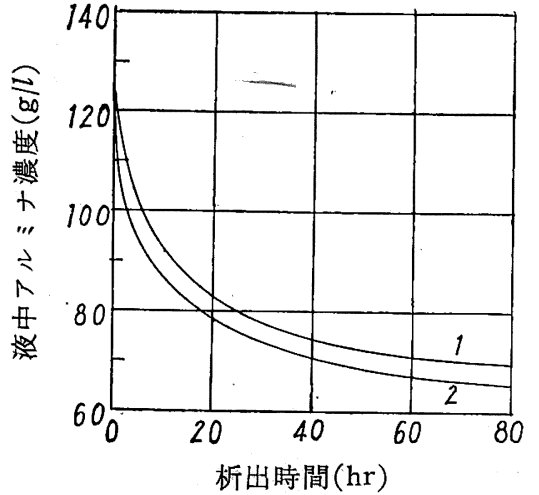

図 17 析出曲線一不純物の影響 （岡田による）

$1:$ 純液 $2:$ 工莱液

純アルミン酸ナトリ ウム溶液と工業液とを 比較して実験を行なっ たものに岡田 ${ }^{17}$ )の研究 がある。一例を挙げる とフッ化アルミニウム 添加により $60^{\circ} \mathrm{C}$ で析 出した活性種子を $5 \%$ 用い, 析出温度 $65^{\circ} \mathrm{C}$ の析出条件による比較 を行なったものが，図 17 のと拈りである。 この時の純アルミン 酸ナトリウム溶液は

$\mathrm{NaOH} 141 \mathrm{~g} / l, \mathrm{Na}_{2} \mathrm{CO}_{3}$ $7.5 \mathrm{~g} / l$, モル比 0.64 で, 工業液は $\mathrm{NaOH}$ $133 \mathrm{~g} / l, \quad \mathrm{Na}_{2} \mathrm{CO}_{3} 34.7$ $\mathrm{g} / l$, モル比 0.65 で工 業液の方がむしろ析出 が早い。更に $60^{\circ} \mathrm{C}$ で $40 \mu$ 以上 $70 \%$ の粗粒 種子を種子量 $70 \%$ 使 用して行った実験結果

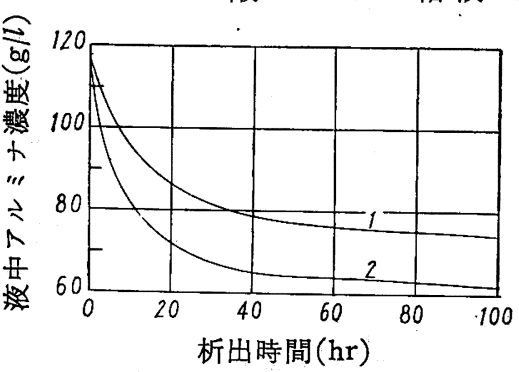

図 18 析出曲線一不純物の影響 (岡田火よる)

1 : 純液 $2:$ 工栄液 を図 18 に揭げる。この時の純アルミン酸ナトリウム溶液は $\mathrm{NaOH}$ $146 \mathrm{~g} / l, \mathrm{Na}_{2} \mathrm{CO}_{3} 6.5 \mathrm{~g} / l$, モル比 0.69 で工業液は $\mathrm{NaOH} 145$ $\mathrm{g} / l, \mathrm{NaCO}_{3} 38 \mathrm{~g} / l$, モル比 0.63 であった。この場合でも工業液 の方が析出が早く進んでいる。

Herrmann ${ }^{6)}$ は $\mathrm{NaOH} 141 \mathrm{~g} / l$, モル比 0.56 の純アルミン酸 ナトリウム溶液と $\mathrm{NaOH} 149 \mathrm{~g} / l$, モル比 $0.53, \mathrm{Na}_{2} \mathrm{CO}_{3} 25.4$ $\mathrm{g} / l, \quad \mathrm{Na}_{2} \mathrm{SO}_{4} 11.95 \mathrm{~g} / l, \quad \mathrm{NaCl} 0.8 \mathrm{~g} / l, \quad \mathrm{Cr}_{2} \mathrm{O}_{3}<0.1 \mathrm{~g} / l, \quad \mathrm{~V}_{2} \mathrm{O}_{5}<$ $0.29 \mathrm{~g} / l, \mathrm{P}_{2} \mathrm{O}_{5}<0.1 \mathrm{~g} / l, \mathrm{SiO}_{2} 0.5 \mathrm{~g} / l$, 赤泥残留物 $0.01 \mathrm{~g} / l$, 有 機物こん跡の工業用アルミン酸ナトリウム溶液を使用し，初温 $60^{\circ} \mathrm{C}$, 終温 $35^{\circ} \mathrm{C}$, 活性種子 $1 \%$ を加立て析出実験を行ない, 図 19 のような結果を得た。この場合, 工業液の方が析出初期に拈 ける遅帯がなくなっている。また，純アルミン酸ナトリウム溶液 でも種子量を増加すれば，点線で示したように遅滞がなくなると している。

以上のような結果から見ると工業液には析出を早めるなんらか

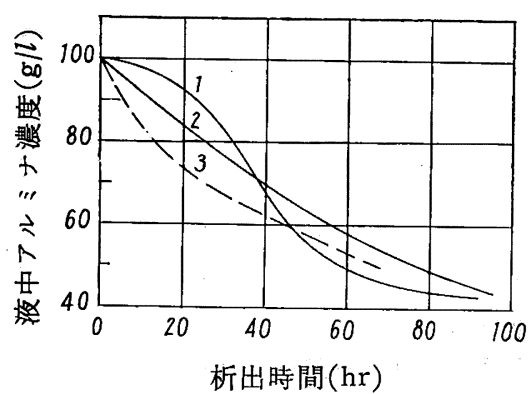

図 19 析出曲線一不純物の影響 (Herrmann Kよる)

$1:$ 純波程子最 $(\%) \quad 1$

3 : 維 液 " 2.5

17）岡田，昭和電工横浜工場報 155 (1955)；286 (1959). の作用があると考えら れる。Herrmann の使 用した液では炭酸ナト リウム, 硫酸ナトリウ ムの多いのが目立って いるが，岡田の使用し た液では炭酸ナトリウ ム，塩化ナトリウム， 有機物が特に多い。し たがって，両者に共通 な炭酸ナトリウムがそ の原因ではないかと見 
られる。

これについては伊藤 ${ }^{18)}$ の実験によれば $\mathrm{NaOH} 145 \mathrm{~g} / l$, モル比 $0.49,40^{\circ} \mathrm{C}$ の析出条件に打いて, $\mathrm{Na}_{2} \mathrm{CO}_{3} 20 \sim 30 \mathrm{~g} / \mathrm{l}$ まで添加す ると析出速度の増加が認められて扣り，その原因としては $\mathrm{Na}_{2} \mathrm{O}$. $\mathrm{Al}_{2} \mathrm{O}_{3} \cdot 4 \mathrm{CO}_{2} \cdot x \mathrm{H}_{2} \mathrm{O}$ なる複塩の生成のためか, 水酸化アルミニウ 么粒子の凝集を起すためのいずれかであるとしている。

更に木村 ${ }^{19)}$ によれば $\mathrm{NaOH}$ の中の $0 \sim 20 \mathrm{~g} / l$ 程度を $\mathrm{Na}_{2} \mathrm{CO}_{3}$ に置換せしめると置換量が多いほど析出量が増すといっている。 かかる実験的事実から推論すれば，工業液に拈ける析出速度の增 加の原因は炭酸ナトリウムに起因するものと考えられる。更に後 述すると括り，液中に炭酸ガスを多くもたらす空気かきまぜに おいては析出物中に含有するナトリウム分を多くするという事夷 は，析出の促進が伊藤のいうような複塩の生成に起因するものと 思われる。

他の塩, すなわち塩化ナトリウム, 硫酸ナトリウムについては 塩田 ${ }^{20)}$ ，木村の実験があり，いずれも悪い影響があるといってい る。Pearson ${ }^{21)}$ は通常の純アルミン酸ナトリウム溶液において法 析出速度は次式に従うとしている。

$$
-\frac{\mathrm{d} C_{\mathrm{a}}}{\mathrm{d} \theta}=K A_{\mathrm{t}}\left(\frac{C_{\mathrm{a}}-C_{\mathrm{as}}}{C_{\mathrm{n}}}\right)
$$

18）伊藤，フルミニウム 3 ，A 192 (1943).

19）木村，フルミニウム 4, A 132 (1944).

20) 塩田，アルミニウム 3，49 (1943).

21) T. G. Pearson, "The Chemical Background of Aluminium Industry" p. 30 (1955), W. Heffer \& Sons Ltd, Cambridge.

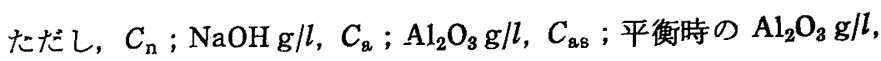
$A_{\mathrm{t}}$; 種子表面積, $K$; 反応速度定数とする。工業用溶液を使用し た場合には $C_{\mathrm{ass}}$ が $C^{\prime}{ }_{\mathrm{as}}\left(C_{\mathrm{as}}<C^{\prime}{ }_{\mathrm{as}}\right)$ に変化するので析出速度は

$$
-\frac{\mathrm{d} C_{\mathrm{a}}}{\mathrm{d} \theta}=K A_{\mathrm{t}}\left(\frac{C_{\mathrm{a}}-C_{\mathrm{aB}}^{\prime}}{C_{\mathrm{n}}}\right)^{2}
$$

となり，毒作用係数として

$$
k=\frac{C_{\mathrm{as}}^{\prime}-C_{\mathrm{as}}}{C_{\mathrm{as}}} \text {. }
$$

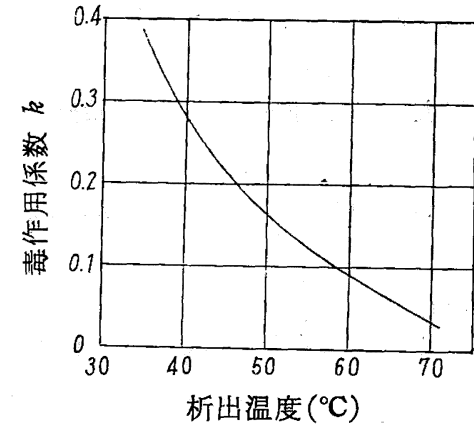

図 20 毒作用係数 (Pearson Kよる)
を定義すれば, $k$ は濃度が 一定ならば, 高温程減少し 毒作用の低下することを示 している（四 20)。この結 果はいずれの場合でも純液 より析出速度が小さくなる ことを意味し，先に示した 実験的事実と食違ってい る。おそらく使用した工業 用アルミン酸ナトリウム溶 液中の不純物成分のちがい

から来るものであろう。

一般に有機物が析出を阻害することは Pearson，木村の実験で も述べられている。たた，デンプンだけは佐藤 ${ }^{22)}$ の実験によると 析出速度を促進する。

本報告の終に当り，発表の機会を与えていただき，かつ種々の 御指導, 御援助を賜わった昭和電工一方井卓雄重役, 松原一郎工 場長を始め, 諸先䨿の方々に深く感謝の意を表わす。

\title{
アルミン酸ナトリウム溶液からの水酸化アルミニウムの 析出物粒度に対する溶液の温度および組成の影響†
}

(昭 和 37 年 3 月 20 日受 理)

\author{
下里純一郎**古川晶 久 $^{* *} \cdot$ 高 橋一太
}

\begin{abstract}
バイヤー法によるアルミナ製造工程に扣いてアルミン酸ナトリウム溶液から析出する水酸化アルミニゥムの性状は, 析 出工程以後の工程すなわち結晶の溶液からの分離, 脱水, 並びに焼成してアルミナを生成する諸工程の能率を支配する上 で重要である。本報に拈いては析出物の粘度に影響を及ぼす反応諸条件の中から，溶液の温度並びに組成を選び，これら の要因による変動を調べた実験を行ない，更に従来の文献上の実験例をも加えてその影響を論じた。この結果，次のよう な傾向が指摘された。（1）析出初温並びに析出過程の温度経過はともに高温の方が析出物の粒度は大になる。ただし析 出過程の温度よりも析出初温の方が影響は大きい。（2）アルカリ濃度の影響は高温に括けるょりも低温の方が著しい。 高温ではフルカリ濃度の濃い方が若干細かい析出物を生成するが，低温では粒度が最も細かくなるアルカリ濃度が存在 し，かつ低温になるに従い，その最小点はアルカリ濃度の薄い方に移る。
\end{abstract}

\section{1 緒言}

アルミン酸ナトリウム溶液から析出する際の水酸化アルミニウ ムの純度は反応条件によって，多種多様の変化を受ける。析出反 応の条件を核が発生し易く，過飽和度の高い条件汉って，しか

$\dagger$ 本報を「アルミナ製造工程より見たアルミン酸ナトリウム 溶液からの水酸化アルミニウムの析出反応（第 5 報）」と する。

* 昭和ネオプレン株式会社技術部：東京都港区芝宮本町

** 昭和電工株式会社横浜工場：横浜市神奈川区恵比須町
も活性ある種子を使えば，細粒が発生するし，その逆の条件で反 応を行なわせれば粗粒を製造することができる。アルミナの製造 工程においては，一般に反忘速度を促進せしめるように析出条件 を維持することも必要であるが，生成した析出物の処理を考慮す れば、析出物があまりに微細な結晶であっては思わしくない。し たがって析出条件を選ぶこは，主として両者が適当に満足し合う ような条件を見出だすことが必要である。反応条件を决定する要 因として，本報に颃いては温度，液組成を取り上げ，析出物粓度 に対する影響を調べる。 